\title{
RANCANG BANGUN SISTEM INFORMASI MANAJEMEN KEGIATAN EKSTRAKURIKULER BERBASIS WEB (STUDI KASUS : SMK MA'ARIF KALIREJO LAMPUNG TENGAH)
}

\author{
Dwi Herlina Wati $^{1)}$, Yuri Rahmanto' ${ }^{2}$, Yusra Fernando ${ }^{3)}$ \\ ${ }^{I}$ Sistem Informasi, Universitas Teknokrat Indonesia \\ ${ }^{2}$ Teknik Komputer Universitas Teknokrat Indonesia \\ ${ }^{3}$ Informatika, Universitas Teknokrat Indonesia \\ Jl. Zainal Abidin Pagar Alam No.9-11, Labuhan Ratu, Bandar Lampung, Lampung 35132
}

Email: $\underline{\text { dwiherlinawati4@gmail.com }}^{\text {I) }}{ }^{\text {yurirahmanto@teknokrat.ac.id }}{ }^{2)}$, nando.tekno@gmail.com $^{3)}$

\begin{abstract}
Abstrak
Ekstrakurikuler dalam pendidikan dimaksudkan sebagai jawaban atas tuntutan dari kebutuhan didik, membantu mereka yang kurang memperkaya lingkungan belajar dan memberikan stimulasi kepada mereka agar lebih kreatif. Suatu kenyataan bahwa banyak kegiatan pendidikan yang tidak selalu dapat dilakukan dalam jam-jam sekolah yang terbatas itu, sehinga terbentuklah perkumpulan anak-anak diluar jam sekolah yang dianggap dapat menampung dan memenuhi kebutuhan serta minat mereka.

Pengelolaan kegiatan ekstrakurikuler pada SMK Ma'rif Kalirejo Lampung Tengah memiliki kendala, siswa yang mendaftar ekstrakurikuler mengumpulkan formulir pendaftaran sehingga menyebabkan penumpukan berkas. Penyampaian informasi ekstrakurikuler dengan cara ketua kelas menyampaikan kemasing-masing kelas, hal tersebut tentu akan menyita banyak waktu.

Dari permasalahan diatas maka penulis membuat sebuah sistem informasi manajemen kegiatan ekstrakurikuler berbasis web dengan menggunakan bahasa pemrograman PHP, database MySQL dan dirancang menggunakan Unified Modeling Language $(U M L)$. Sistem ini diuji menggunakan metode pengujian ISO 9126 mengunakan aspek functionality dan usability. Hasil dari penelitian ini adalah sebuah sistem yang dapat membantu Pembina ekstrakurikuler dalam mengelola kegiatan ekstrakurikuler dan ketua ekstrakurikuler dalam mengelola informasi kegiatan ekstrakurikuler secara mudah.
\end{abstract}

Kata Kunci : Sistem Informasi Manajemen, Ekstrakurikuler, ISO 9226

\section{Pendahuluan}

Pengembangan dan perbaikan pendidikan baik segi akademik maupun nonakademik dilakukan terus menerus untuk mencapai hasil yang maksimal. Secara akademik peserta didik diberikan pembelajaran mengenai ilmu-ilmu seperti mata pelajaran matematika, fisika, kimia dan sebagainya. Dari segi nonakademik peserta didik diberikan pembelajaran mengenai keterampilan-keterampilan sesuai dengan minat dan bakat untuk masa depannya. Untuk mencapai hasil yang maksimal tersebut tidak hanya cukup dicapai dengan pendidikan formal saja namun juga dengan pendidikan nonformal atau ekstrakurikuler.

Ekstrakurikuler pada SMK Ma'arif Kalirejo saat ini sudah mulai berkembang, selain mengutamakan pendidikan formal SMK Ma'arif juga mengutamakan pendidikan nonformal. Pendaftar anggota baru perekstrakurikuler di SMK Ma'arif mencapai lebih dari 20 pendaftar. SMK Ma'arif mengenalkan ekstrakurikulernya kepada masyarakat melalui lombalomba ekstrakurikuler yang diikuti. Ekstrakurikuler di SMK Ma'arif sudah pernah meraih juara pada tingkat kabupaten dan provinsi. Adapun jenis-jenis ekstrakurikuler yang ada yaitu, Bidang akademik seperti Japan Club, English Club, Robotik dan Karya Ilmiah Remaja (KIR), bidang minat bakat seperti Seni Bela Diri (Pagar Nusa), Futsal, Volly, Tari, Patroli Keamanan Sekolah (PKS), Usaha Kesehatan Siswa (UKS), Rohis, Kepramukaan, Paskibra, dan Angklung.

Proses pengelolaan kegiatan ekstrakurikuler pada SMK Ma'arif Kalirejo Lampung Tengah masih memiliki kendala. Data yang harus diolah dan diinformasikan dengan cepat merupakan hal yang perlu diutamakan. Namun, karena belum adanya sistem informasi manajemen menyebabkan pelayanan kegiatan ekstrakurikuler belum maksimal. Setiap siswa yang akan mendaftar ekstrakurikuler harus mengisi dan mengumpulkan formulir pendaftaran kegiatan ekstrakurikuler yang ingin diikuti. Sehingga menyebabkan penumpukan berkas pendaftaran yang membuat pembina ekstrakurikuler kerepotan dalam merekap data pendaftar yang masuk. Selain itu penyampaian informasi berkaitan dengan kegiatan ekstrakurikuler dengan cara menyampaikan informasi ke masing-masing kelas. Hal tersebut tentu menyita banyak waktu karena ketua ekstrakurikuler merupakan salah satu siswa SMK Ma'arif, sehingga ketua ekstrakurikuler sering izin dan ketinggalan mata pelajaran. 
Berkaitan dengan hal tersebut, penelitian ini mengacu untuk membuat sistem informasi manajemen dalam kegiatan ektrakurikuler yang ada di sekolah SMK Ma'arif Kalirejo Lampung Tengah. Kurangnya pengelolaan dan perhatian dalam pengelolaan kegiatan ekstrakurikuler di sekolah salah satunya disebabkan oleh kurangnya pemanfaatan teknologi. Salah satu penyelesaian untuk meminimalisir pengelolaan informasi agar lebih cepat, tepat, dan akurat dengan membuat aplikasi aplikasi berbasiskan web, yang lebih sering di sebut dengan aplikasi internet. Sistem informasi berbasis web adalah suatu portal internet yang berisi suatu sistem untuk menampilkan informasi-informasi sehingga akan lebih mudah dan cepat diakses dan dipahami oleh pengguna (Mulyani \& Muhammad Fadilah, 2017).

Berdasarkan permasalahan yang digambarkan diatas, maka penelitian ini berfokus pada Rancang Bangun Sistem Informasi Manajemen Ektrakurikuler Berbasis Web, Studi Kasus SMK Ma'arif Kalirejo Lampung Tengah, yang nantinya dapat digunakan untuk membantu para siswa dalam memilih kegiatan ekstrakurikuler secara online, dan mendapatkan informasi secara mudah serta membantu pembina ekstrakurikuler dalam proses pengolahan data ekstrakurikuler.

\section{Pembahasan}

\subsection{Sistem Informasi Manajemen}

Sistem informasi manajemen adalah suatu metode untuk menghasilkan informasi yang tepat waktu bagi manajemen tentang lingkungan luar organisasi dan kegiatan operasi didalam organisasi, dengan tujuan untuk menunjang proses pengambilan keputusan serta memperbaiki proses perencanaan dan pengawasannya (Sutabri, 2005).

\subsection{Tahapan Penelitian}

Tahapan penelitian merupakan lanjutan dari kerangka penelitian, tahapan penelitian dapat dilihat pada gambar berikut ini:

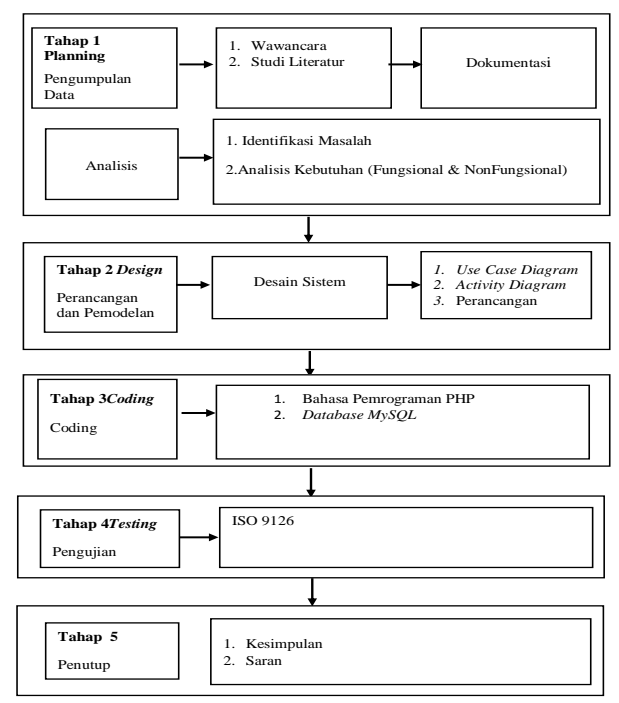

Gambar 1. Tahapan Penelitian

\subsection{Pengumpulan Data}

Teknik pengumpulan data yang dilakukan penulis dalam penelitian ini adalah sebagai berikut :

a. Wawancara

Metode ini dilakukan dengan cara melakukan tanya jawab secara langsung kepada pembina ekstrakurikuler terhadap permasalahan yang berhubungan secara langsung.

b. Studi Literatur

Studi literatur dilakukan kajian literatur dari beberapa jurnal, E-book, buku-buku referensi dan sumber sumber lain yang berkaitan dan dapat mendukung dalam pembuatan penelitian ini.

c. Dokumentasi

Dokumentasi yang digunakan pada penelitian ini adalah dokumentasi dari kegiatan observasi serta proses wawancara yang dilakukan oleh peneliti.

\subsection{Design}

Rancangan sistem dalam tahap ini digunakan untuk menggambarkan desain sistem yang diusulkan dengan menggunakan pemodelan UML (Unifield Modeling Language) yang berorientasi objek yaitu use case diagram yang dapat mempermudah pembuatan sistem.

\subsection{Perancangan Use Case}

Berikut adalah use case rancang bangun sitem informasi manajemen kegiatan ekstrakurikuler berbasis web yang akan dibangun, dapat dilihat pada Gambar 2 sebagai berikut:

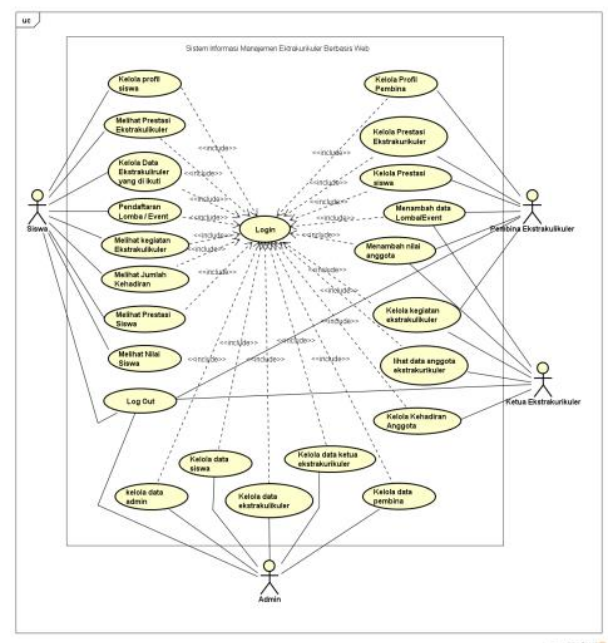

Gambar 2. Use Case Diagram

\subsection{Rencana Pengujian ISO 9126}

Dalam pengujian perangkat lunak ini penulis menggunakan suatu metode pengujian yang berfokus pada persyaratan fungsional perangkat lunak yang dibangun. Pengujian sistem ini akan diuji oleh pemilik kost dan calon penyewa dengan menggunakan metode yang diambil adalah metode pengujian ISO 9126 berdasarkan Functionality dan Usability. Untuk mengukur suatu variabel yang akan diteliti maka peneliti menggunakan instrument penelitian skala likert. 
Pada aspek Usability, pengujian menggunkan instrumen penelitian berupa test case dengan skala likert. Skala likert dapat digunakan untuk mengukur sikap, pendapat dan persepsi seseorang atau sekelompok orang tentang fenomena sosial. Dalam penelitian fenomena sosial ini diterapkan secara spesifik oleh penelitian, yang selanjutnya disebut dengan variabel. Dengan adanya skala likert, maka variabel yang akan diukur dijabarkan menjadi indikator variabel, sehingga dapat menjadi titik tolak untuk menyusun instrument yang dapat berupa pernyataan atau pertanyaan (Sugiyono, 2016).

Sedangkan pada aspek functionality, pengujian menggunakan instrumen penelititan berupa test case dengan skala Guttman. Skala Guttman digunakan pada penelitian apabila ingin mendapatkan jawaban yang tegas terhadap suatu permasalahan yang ingin ditanyakan (Sugiyono, 2016). Skala pengukuran dengan tipe ini didapat jawaban yang tegas, yaitu "ya-tidak", "benar-salah", "sukses-gagal" dan lain-lain. Berikut adalah rencana pengujian yang ingin dilakukan, diantaranya sebagai berikut :

Tabel 1. Skala Likert

\begin{tabular}{|c|c|}
\hline Jawaban & Skor \\
\hline Sangat Setuju & 5 \\
\hline Setuju & 4 \\
\hline Netral & 3 \\
\hline Tidak Setuju & 2 \\
\hline Sangat Tidak Setuju & 1 \\
\hline
\end{tabular}

Kemudian data yang didapat dianalisis dengan menghitung rata-rata jawaban berdasarkan skor setiap jawaban responden yang ada diangket fungsional suitability. Berdasarkan skor yang telah didapat ditetapkan rumus perhitungan hasil pengujian fungsional suitability sebagai berikut :

$$
=\frac{\text { Persentase }}{\text { skor hasil pengujian }} \times 100 \%
$$

Berdasarkan skor yang telah didapat ditetapkan rumus perhitungan hasil pengujian usability sebagai berikut :

$$
\begin{aligned}
& \text { Persentase } \\
& =\frac{\text { skor hasil pengujian }}{\text { skor tertinggi }} \times 100 \%
\end{aligned}
$$

Hasil perhitungan aspek usability dihitung yang kemudian di tetapkan berdasarkan rentang kriteria kualitas pengujian aspek usability yang dapat dilihat pada tabel 2 sebagai berikut:

Tabel 2. Rentang kriteria kualitas pengujian aspek usability

\begin{tabular}{|c|c|l|}
\hline No & Rentang kriteria & \multicolumn{1}{|c|}{ Kriteria } \\
\hline 1 & $0 \%-20 \%$ & Sangat Tidak Layak \\
\hline 2 & $21 \%-40 \%$ & Tidak Layak \\
\hline 3 & $41 \%-60 \%$ & Kurang Layak \\
\hline 4 & $61 \%-80 \%$ & Layak \\
\hline 5 & $81 \%-100 \%$ & Sangat Layak \\
\hline
\end{tabular}

\subsection{Implementasi Program}

Sistem atau implementasi merupakan tahap dimana sistem sudah siap dioperasikan. Berikut hasil implementasi rancangan interface:

1. Form Menu Data Ekstrakurikuler

Pada halaman menu data ekstrakurkuler dalam website ini merupakan tampilan menu ekstrakurikuler yang berfungsi untuk menginput data ektrakrikuler dan mengubah data ekstrakuriuler dengan cara mengklik tombol tambah ekstrakurikuler untuk menambah ekstrakurikuler dan mengklik aksi untuk mengubah ekstrakurikuler. Form data ekstrakurikuler dapat dilihat pada gambar 3:

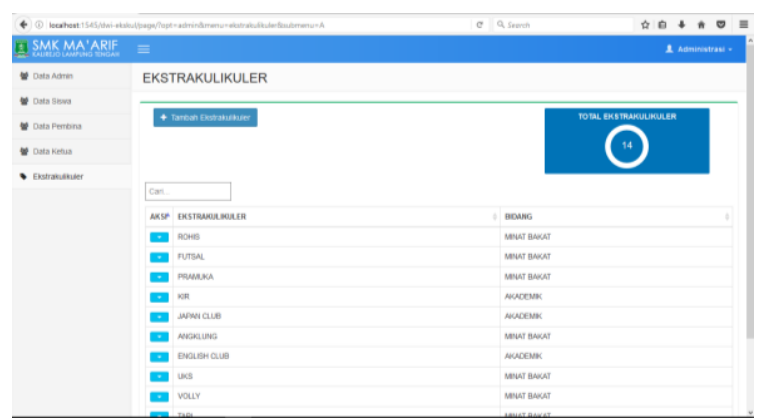

Gambar 3. Form Menu Data Ekstrakurikuler

2. Form Menu Ekstrakurikuler Sebagai Siswa

Pada halaman menu kegiatan ekstraurikuler dalam website ini merupakan tampilan menu kegiatan ekstrakurikuler yang berfungsi untuk melihat kegiatan ekstrakurikuler di masing-masing ekstraurikuler. Form menu kegiatan ekstrakurikuler dapat dilihat pada gambar 4:

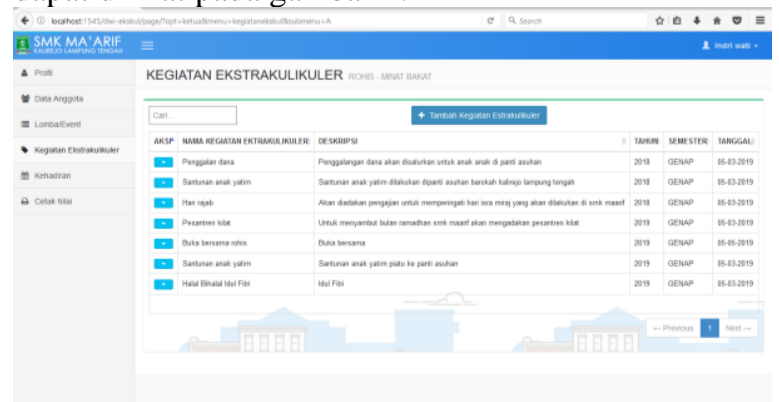

Gambar 4. Form Menu Data Ekstrakurikuler Sebagai Siswa

3. Form Menu Prestasi

Pada halaman menu prestasi ekstrakurikuler dalam website ini merupakan tampilan menu prestasi ekstrakurikuler yang berfungsi untuk melihat prestasi anggota yag diraih di masing-masing ekstraurikuler, Form menu prestasi dapat dilihat pada gambar 5: 


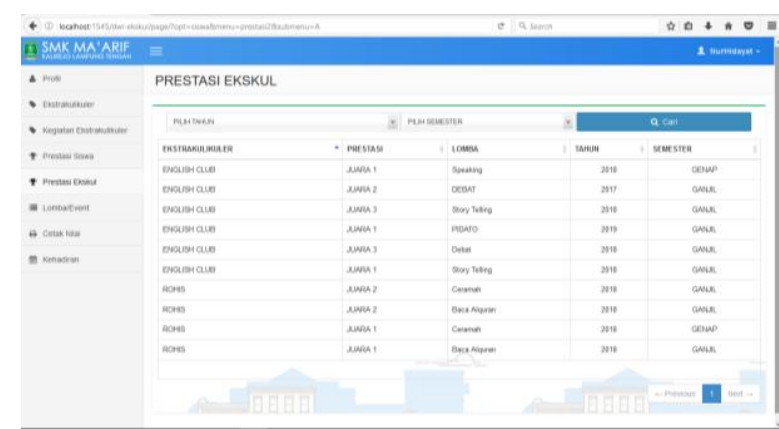

Gambar 5. Form Menu Prestasi

\subsection{Hasil pengujian Functionality}

Pada pengujian functionality kuesioner diisi oleh orang yang memiliki keahlian dalam bidang software engineering untuk mengetahui apakah fungsi - fungsi pada sistem dapat berjalan dengan benar. Jumlah pernyataan dalam kuesioner tersebut yaitu 12 pernyataan dengan menggunakan skala $\mathrm{SS}=5, \mathrm{~S}=4, \mathrm{~N}=3, \mathrm{TS}=2$,

STS $=1$. Hasil dapat dilihat pada tabel 4 sebagai berikut:

a. Identitas Responden

Nama : Sampurna Dedi

Pekerjaan : Dosen Tetap Universitas Teknokrat Indonesia

b. Angket

Tabel 3. Hasil pengujian functionality

\begin{tabular}{|c|c|c|c|}
\hline \multirow{2}{*}{ NO } & \multirow{2}{*}{ FUNGSI } & \multicolumn{2}{|c|}{ HASIL } \\
\hline & & SUKSES & GAGAL \\
\hline 1. & $\begin{array}{l}\text { Apakah sistem dapat } \\
\text { menampilkan menu } \\
\text { utama dan menu- } \\
\text { menu } \\
\text { dibutuhkan dalam } \\
\text { melakukan masukan } \\
\text { data atau informasi } \\
\text { yang dibutuhkan } \\
\text { dalam pengelolaan } \\
\text { data sistem informasi } \\
\text { manajemen kegiatan } \\
\text { ekstrakurikuler } \\
\text { dengan benar }\end{array}$ & 1 & 0 \\
\hline 2. & $\begin{array}{l}\text { Apakah sistem dapat } \\
\text { mengelola data siswa } \\
\text { seperti :ubah data, } \\
\text { simpan data }\end{array}$ & 1 & 0 \\
\hline 3. & $\begin{array}{l}\text { Apakah sistem dapat } \\
\text { mengelolah data } \\
\text { pembina seperti : } \\
\text { ubah data, simpan } \\
\text { data }\end{array}$ & 1 & 0 \\
\hline 4. & $\begin{array}{l}\text { Apakah sistem dapat } \\
\text { mengelola data } \\
\text { prestasi siswa seperti: } \\
\text { tambah data, ubah } \\
\text { data, simpan data, } \\
\text { hapus data }\end{array}$ & 1 & 0 \\
\hline 5. & Apakah sistem dapat & 1 & 0 \\
\hline
\end{tabular}

\begin{tabular}{|c|c|c|c|}
\hline & $\begin{array}{l}\text { mengelolah } \\
\text { admin seperti: ubah } \\
\text { data }\end{array}$ & & \\
\hline 6. & $\begin{array}{l}\text { Sistem } \\
\text { pesan } \\
\text { pemberitauan } \\
\text { terhadap berupa } \\
\text { seperti : jika berhasil } \\
\text { masuk ke sistem, } \\
\text { maka sistem akan } \\
\text { menampilkan pesan, } \\
\text { "Login pembina } \\
\text { berhasil, Selamat } \\
\text { datang" }\end{array}$ & 1 & 0 \\
\hline 7. & $\begin{array}{l}\text { Apakah sistem dapat } \\
\text { mengelola data } \\
\text { ekstrakurikuler } \\
\text { seperti: tambah data, } \\
\text { ubah data, simpan } \\
\text { data, hapus data }\end{array}$ & 1 & 0 \\
\hline 8. & $\begin{array}{l}\text { Sistem memberi } \\
\text { pesan berupa dialog } \\
\text { box terhadap aksi } \\
\text { tertentu, seperti: jika } \\
\text { ingin menghapus } \\
\text { salah satau data maka } \\
\text { sistem menampilkan } \\
\text { dialog, "Anda yakin } \\
\text { akan menghapus } \\
\text { data?" }\end{array}$ & 1 & 0 \\
\hline 9. & $\begin{array}{lr}\text { Sistem } & \text { dapat } \\
\text { menampilkan } & \text { data } \\
\text { kegiatan } & \\
\text { ekstrakurikuler } & \\
\text { dengan cepat dan } \\
\text { tepat }\end{array}$ & 1 & 0 \\
\hline 10. & $\begin{array}{l}\text { Sistem dapat } \\
\text { menampilkan laporan } \\
\text { nilai siswa }\end{array}$ & 1 & 0 \\
\hline 12. & $\begin{array}{ll}\text { Sistem } & \text { dapat } \\
\text { melakukan } & \text { login } \\
\text { dengan baik } & \\
\end{array}$ & 1 & 0 \\
\hline 13. & $\begin{array}{lr}\text { Sistem } & \text { dapat } \\
\text { melakukan } & \text { logout } \\
\text { dengan baik } & \\
\end{array}$ & 1 & 0 \\
\hline
\end{tabular}

Selanjutnya dilakukan perhitungan persentase untuk pengujian aspek functionality yaitu sebagai berikut :

$$
\begin{aligned}
& \text { Persentase } \\
& =\frac{\text { skor hasil pengujian }}{\text { skor tertinggi }} \times 100 \% \\
& =\frac{13}{13} \times 100 \%=100 \%
\end{aligned}
$$

\subsection{Hasil pengujian $U$ sability}

Sedangkan untuk standar skenario penelitian kebutuhan user menggunakan standar kualitas ISO 9126 usability testing , adapun pengujian usability dilakukan terhadap 30 responden melalui media kuisioner yang dapat dilihat pada halaman lampiran. Jumlah pernyataan dalam 
kuesioner tersebut yaitu 11 pernyataan dengan menggunakan skala $\mathrm{SS}=5, \mathrm{~S}=4, \mathrm{~N}=3, \mathrm{TS}=2, \mathrm{STS}=1$. Hasil perhitungan yang didapatkan selanjutnya dibandingkan dengan mengkriteria interprestasi skor dengan rentang. Didapatkan hasil kelayakan tiap sub aspek usability dari 30 responden, dengan hasil yang dapat dilihat pada tabel 4 sebagai berikut :

Tabel 4. Hasil Kelayakan sub aspek Usability

\begin{tabular}{|l|l|l|l|}
\hline No & Aspek & Persentase & $\begin{array}{l}\text { Tingkat } \\
\text { Kelayakan }\end{array}$ \\
\hline 1. & Operability & $83,55 \%$ & $\begin{array}{l}\text { Sangat } \\
\text { Layak }\end{array}$ \\
\hline 2. & Learnbility & $89,77 \%$ & $\begin{array}{l}\text { Sangat } \\
\text { Layak }\end{array}$ \\
\hline 3. & Understandability & $87,66 \%$ & $\begin{array}{l}\text { Sangat } \\
\text { Layak }\end{array}$ \\
\hline 4. & Attractiveness & $92.22 \%$ & $\begin{array}{l}\text { Sangat } \\
\text { Layak }\end{array}$ \\
\hline
\end{tabular}

Selanjutnya dilakukan perhitungan persentase untuk pengujian aspek usability secara keseluruhan dari data hasil pengujian menggunakan rumus :

$$
\begin{aligned}
\text { usability } & =\frac{\begin{array}{l}
\text { Persentase } \\
\text { skor hasil pengujian } \\
\text { skor tertinggi }
\end{array}}{} \times 100 \% \\
& =\frac{1,442}{1,650} \times 100 \%=87,39 \%
\end{aligned}
$$

\subsection{Analisis Hasil Pengujian}

Sistem informasi manajemen kegiatan ekstrakurikuler berbasis web diuji dalam tahap uji kualitas software ISO 9126 (Functionality dan Usability). Hasil pengujian sistem informasi manajemen kegiatan ekstrakurikuler berbasis web dapat dilihat pada tabel 5 sebagai berikut:

Tabel 5. Hasil Pengujian Sistem

\begin{tabular}{|l|l|}
\hline \multicolumn{1}{|c|}{ Aspek } & \multicolumn{1}{|c|}{ Hasil } \\
\hline Functionality & $\begin{array}{l}\text { Sistem dapat melakukan 100\% } \\
\text { fungsinya dengan benar }\end{array}$ \\
\hline Usability & $\begin{array}{l}\text { Pengujian aspek usability } \\
\text { diperoleh nilai persentase sebesar } \\
87,39 \%\end{array}$ \\
\hline
\end{tabular}

Berdasarkan Berdasarkan tabel 5 berikut hasil analisis hasil pengujian :

1. Analisis Hasil Functionality

Berdasarkan angket yang diisi oleh orang yang memiliki keahlian dalam bidang softwate engineering, menunjukan hasil bahwa fungsi fungsi pada sistem informasi manajemen kegiatan ekstrakurikuler berbasis web dapat berjalan dengan benar, tidak adanya tombol yang tidak berfungsi dan tombol memunculkan perintah yang sesuai.
2. Analisis Hasil Usability

Pada hasil usability yang diisi oleh 30 responden menunjukkan bahwa sistem informasi manajemen kegiatan ekstrakurikuler berbasis web sangat bagus dalam penggunaan, operasi yang sangat mudah, dapat membantu dalam pengolahan anggota siswa yang mendaftar dan menyebarkan informasi dengan mudah.

\section{Kesimpulan}

Sistem informasi manajemen kegiatan ekstrakurikuler berbasis web di SMK Ma'arif Kalirejo Lampung Tengah dibuat menggunakan bahasa pemrograman PHP dan DBMS MySQL yang dapat membantu Pembina dalam mengelola pendaftar ekstrakurikuler yang ditunjukkan pada menu ekstrakurikuler dimana siswa dapat memilih ekstrakurikuler yang ingin diikuti, selain itu sistem informasi manajemen kegiatan ekstrakurikuler dapat membantu ketua ekstrakurikuler dalam memberikan informasi mengenai kegiatan ekstrakurikuler yang ditunjukkan pada menu kegiatan ekstrakurikuler.

Hasil pengujian terhadap sistem dari sisi functionality menghasilkan kesimpulan bahwa sistem dapat melakukan $100 \%$ fungsinya dengan benar, dan dari sisi usability menghasilkan kesimpulan bahwa sistem informasi manajemen kegiatan ekstrakurikuler berbasis web sangat layak untuk digunakan, operasi yang sangat mudah, dapat membantu dalam pengolahan anggota siswa yang mendaftar dan menyebarkan informasi dengan mudah.

Adapun saran yang diberikan yaitu, diharapkan data dan informasi ekstrakurikuler di dalam database sistem untuk selalu diperbaharui, sebab akan sangat membantu untuk mempermudah Pembina, ketua dan siswa. Dalam penelitian selanjutnya diharapkan Sistem Informasi ini bisa ditambahkan presensi siswa secara online.

\section{Daftar Pustaka}

MULYANI, A., dan FADILAH, R.R., 2017. Rancang Bangun Sistem Informasi Ekstrakurikuler di Madrasah Aliyah Negeri 1 Garut Berbasis Web. Jurnal Algoritma Sekolah Tinggi Teknologi Garut, p.57.

SUGIYONO. 2016. Metode Penelitian Kuantitatif, Kualitatif dan R\&D. Bandung: PT Alfabet.

SUTABRI, T., 2005. Sistem Informasi Manajemen.. Yogyakarta:Andi Yogyakarta 